On Friday afternoon, at 2.30, the President of the United States, attended by the president of the Society, the Hon. Elihu Root, and the Secretary of War, the Hon. William H. Taft, received the members in attendance at the meeting, and on Saturday evening, at 7 o'clock, the second annual meeting was closed with a banquet at the New Willard Hotel, where one hundred and eleven of the members and guests gathered together The president of the Society presided as toastmaster, and addresses were delivered by the Hon. Oscar S. Straus, Secretary of Commerce and Labor, vice-president of the Society and chairman of the Executive Committee; Gen. Horace Porter, vice-president of the Society; the Reverend Bishop 0'Connell, rector of the Catholic University of America; R. C. Smith, K. C., of Montreal, Canada ; and the Hon. David $J$. Brewer, Justice of the Supreme Court of the United States and vicepresident of the Society.

\title{
THE PENNSYLVANIA ARBITRATION AND PEACE CONFERENCE
}

On May 16 to 19, 1908, a notable conference on arbitration and peace was held in the city of Philadelphia. Its objects, as stated in the published program, were:

First. To promote the universal acceptance of the principles of international arbitration, and the establishment of permanent courts of justice for the nations, as the only practical means to ensure the blessings of peace by making wars improbable, and ultimately impossible, in the civilized world.

Second. To give the people of Pennsylvania an opportunity to commend the splendid record of the United States with regard to arbitration, and to pledge their active and earnest support to every effort of our government to continue the work and to carry out the recommendations of the great Hague Conference of 1907.

Third. To form and provide for an effective representation of public sentiment upon the great issues making for international friendship and world organization that should signalize the Third Hague Conference.

Six sessions of the conference were held, besides the banquet on Tuesday evening and a series of meetings held on Sunday in the various churches in the city.

Hon. Philander C. Knox, Senator of Pennsylvania, was president of the conference. Among the notable men who took part were Hon. David J. Brewer, Justice of the Supreme Court of the United States; Hon. William P. Potter, Justice of the Supreme Court of Pennsylvania; Hon. Edwin S. Stuart, Governor of Pennsylvania; Hon. William Jen- 
nings Bryan, of Nebraska; Hon. William L. Penfield, former Solicitor of the Department of State, counsel for the United States in the Pious Fund Cases, and agent for the United States in the Venezuelan Arbitration Cases at The Hague in 1903; Dr. James Brown Scott, Solicitor, Department of State, Washington, D. C., technical delegate of the United States to the Second Hague Conference; Jackson H. Ralston, esq., Washington, D. C., umpire of the Italian Commission in the Venezuelan Arbitration Cases, and agent for the United States in the Pious Fund Cases; Charles C. Harrison, provost of the University of Pennsylvania; Hon. Wayne MacVeagh, Philadelphia, former Attorney-General of the United States; Hon. Richard Bartholdt, member of Congress from Missouri, president of the United States group of the Interparliamentary Union; Benjamin F. Trueblood, LL.D., secretary of the American Peace Society; and Edwin D. Mead, esq., Boston, vice-president of the American Peace Society.

Many of the addresses which were delivered were valuable contributions to the literature of the arbitration movement; they were much more technical and scientific in character than addresses at such conferences usually are. The proceedings themselves were a demonstration of the fact that the arbitration movement is rapidly advaucing from an ideal and theoretical to a practical and scientific stage in which lawyers skilled in international law must have a controlling part. Some of the addresses are worthy of special mention.

At the great meeting on Monday evening, at the Academy of Music, Dr. Scott presented a paper, discussing the need of an international court of justice. Following closely the argument which he delivered before the Second Peace Conference at The Hague on the same subject, he pointed out the defects of the present system of international arbitration, and quoted Mr. Root's words that "what we need for the further development of arbitration is the substitution of judicial action for diplomatic action; the substitution of a judicial sense of responsibility for a diplomatic sense of responsibility." Dr. Scott then considered the character of the judges who should sit in the international court, the jurisdiction which it should exercise, and the manner in which it should be constituted. The topic last mentioned was of special interest, because of the entire failure of the Second Peace Conference at The Hague to deal with it successfully. Starting upon the assumption that all sovereign states are juridically equal, he pointed out that, considered from the standpoint of material interests, they are very unequal; that 
there is "a sensible relation between population, wealth, and industry, on the one hand, and lawsuits on the other;" and that as the large nations will have more disputes to settle, and therefore more interest in the decisions of the court, they should have a larger representation upon it. Without attempting a solution of the method of distributing the judges among the various nations, he suggests that fifteen or sixteen would be a proper number, pointing out that these judges should be so selected as to be trained in the various systems of law of the world.

Mention should also be made of the excellent paper presented by Jackson H. Ralston, esq., of the Washington bar, in which he took the strong position, supporting it by able argument, that no disputes - not even those said to involve the vital interests, honor, or independence of the nations - should be reserved from arbitration.

Attention should also be called to the exceedingly able address of Judge Penfield upon international courts of justice. His paper was a comprehensive review of the history of international courts of justice and a discussion of their present status and possible future.

The other addresses were by no means without interest, but, with the exception of one discussing the constitutionality of the proposed international prize court, published elsewhere in this number, they were not of a technical nature and are therefore of less interest to the readers of this Journal.

The resolutions adopted by this conference show the very intelligent and advanced position which it took on several subjects. The resolutions follow:

1. We express our profound satisfaction in the long record of the United States as an advocate of international arbitration, and in the great number of cases in which it has secured an honorable settlement of serious difficulties without a resort to war. We especially commend the admirable course of our Government at the Second International Peace Conference at The Hague, and pledge our active and cordial support to every effort to fulfill the recommendations of that conference. There are no other means by which our nation can render so great a service to humanity, or do so much for the moral development and material prosperity of its own citizens.

2. The difficulties which have hitherto prevented a general agreement for the limitation of national armaments should not be permitted to obscure the plain reasonableness and imperative necessity for further efforts in that direction. Modern conditions have made it impossible for any of the leading nations to add materially to their relative military or naval strength, because every addition to the fighting force of one country leads at once to a corresponding increase in the other countries; and these secondary increases are made to serve in their turn as conclusive arguments for still greater and still more injurious and demoralizing 
expenditures and efforts by all the powers. It is obvious that this self-multiplying and self-perpetuating process can end only in physical and financial exhaustion unless it can be halted by some kind of mutual understanding or agreement, and we therefore emphatically endorse the recommendation of the Hague conference that the serious study of this vital problem should be again undertaken by all the nations.

3. We strongly approve the proposal to establish an international prize court at The Hague. We realize the injustice of the present system by which neutral vessels accused of violating the laws of war are judged in the courts of the captor, and by which foreign citizens unjustly deprived of their property can seek redress only through the expensive, unsatisfactory, and wearisome method of diplomatic intervention. We welcome the proposed court not only as providing a speedy and equitable method of adjusting one class of international disputes, but as a happy augury of a more complete system of world judicature to be established in future. We believe that the United States will honor itself by providing for appeals from its courts to the international prize court, and affrming cur belief in the constitutionality of the measure we urge the United States Senate to speedily ratify the convention without waiting for a world agreement relative to the laws concerning maritime captures, believing that the jurists who shall compose the court ean be trusted to decide the law in such cases in full accord with the principles of "justice and equity."

4. We especially congratulate the United States delegation to The Hagne upon its distinguished service in securing the recommendation of the establishment of an international court of arbitral justice in the form agreed upon "as soon as an agreement shall have been reached upon the selection of the judges and the constitution of the court." We call attention to the fact that the recommendation, naming no number of powers who must consent, leaves it open for the court to be established at The Hague so soon as three or more nations shall agree upon the nethod of selecting the judges. Until such a court is created to which the nalions of the earth may resort with the assurance that their disputes will be judicially considered and rightly decided, resort to the law of violence will be in some cases inevitable.

We strongly urge the United States Government to take every action which it may deem expedient to secure the consent of two or more other nations to establish this great world court, believing that in this way it is now possible to render a most signal and memorable service to all mankind.

5. We urge as a matter of primary importance that there shall be a general adoption of the proposal that conferences similar to this shall be held in every State of the Union, for promoting the universal acceptance of the principles of international arbitration and the establishment of permanent courts of justice for the nations, as the only practical means to ensure the blessings of peace by making wars improbable, and ultimately impossible, in the civilized world. Such conferences will serve as the organizers and representatives of public opinion in their respective States. Their executive committees, acting together through delegates or otherwise, will exert a powerful influence in supporting the efforts of our National Government, and in other ways will promote the cause of international arbitration at home and abroad. 
6. The president of this conference is hereby requested and empowered to appoint an executive committee of twenty-five, with power to add to, and to fll vacancies in, its own number. It shall be the duty of the said executive com. mittee to act as the representative of this conference for the continuance of its work and the promotion of its objects, and for those purposes it is authorized in its discretion to confer and cooperate with other bodies or committees or individuals from any part of the United States or other countries. It is also empowered to call another meeting of this conference, or to organize a State association for similar purposes, if it shall at any time find that such action will be advisable.

\section{THE FOURTEENTH LAKE MOHONK CONFERENCE}

It will be remembered that it was at the Mohonk conference of 1905 that the first steps were taken toward the organization of the American Society of International Law and the publication of this Journal. It is, therefore, an especial pleasure to the American Journal of InterNational Law to notice the meeting of the Fourteenth Lake Mohonk Conference on International Arbitration, which met at Mohonk Lake, N. Y., on May 20, 21, and 22, 1908, in response to the generous hospitality and under the wise leadership of Hon. Albert K. Smiley. The conference was large and enthusiastic. For the fourth time the Hon. John W. Foster presided over the conference with his accustomed courtesy and ability.

Among those in attendance were Justice Brewer, of the United States Supreme Court; Chief Justice Moore, of Michigan; ex-Chief Justices Stiness and Matteson, of Rhode Island; Baron Takahira, the Japanese ambassador; Hon. James Brown Scott, Solicitor for the Department of State; Hon. John Barrett, Director of the Bureau of American Republics; Dr. Benjamin F. Trueblood, secretary of the American Peace Society; Mr. Clinton Rodgers Woodruff, secretary of the National Municipal League; Mr. Rollo Ogden, of the New York Evening Post; Mr. Hamilton Holt, of the Independent; Hon. Charles F. Manderson, of Nebraska; Hon. Thomas M. Osborne, mayor of Auburn, Public Service Commissioner of New York State; Hon. Samuel J. Barrows; Hon. Robert Lansing; Gen. Horatio C. King; Hon. W. F. Frear, Governor of Hawaii; Hon. Everett P. Wheeler; Hon. William J. Coombs; and Prof. George G. Wilson, who has been recently designated as one of the representatives of the United States at the International Maritime Conference to be held in London this fall.

The Mohonk conferences have of late year's given special attention to 